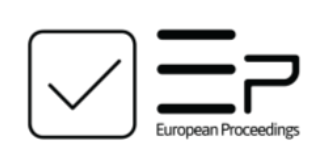

European Proceedings of

International Conference on Education \&

Educational Psychology

EPICEEPSY

www.europeanproceedings.com

e-ISSN: 2672-8141

DOI: $10.15405 /$ epiceepsy.21101.10

ICEEPSY 2021

$12^{\text {th }}$ International Conference on Education \& Educational Psychology

\title{
CZECH UNIVERSITY LANGUAGE TEACHERS' PERSPECTIVES ON THE 2020 PANDEMIC
}

\author{
Hana Pavlisová (a)* \\ *Corresponding author
}

(a) Palacky University Olomouc, Faculty of Education, Department of Technical Education and Information, Žižkovo náměstí 5, 77140 Olomouc, Czech Republic, hana.pavlisova01@upol.cz

\begin{abstract}
Following the WHO's declaration of a global pandemic in March 2020, the Czech Republic applied social distancing and a lockdown which has had a serious impact on students and educators alike. Although distance and blended learning are modes well established and commonly used in the country, it can be assumed that the hasty shift online caught university teachers off guard, confronting them with challenges but also opportunities for professional development. We investigated covid-related changes as perceived by university language teachers. The research sample consisted of 70 randomly chosen teachers who work at departments of education at 9 Czech universities and teach languages to future teachers of various specializations. The online questionnaire survey was conducted over March 2021, one year after the introduction of the country-wide safety measures, allowing thus respondents to reflect on the whole year and verbalize their overall experience. Apart from a more general Preferences section, the questionnaire comprised 34 Likert-scale items that covered three key areas: Course, Lesson, and Support. Prior to interpreting the data, the reliability of the research tool was determined $(r=0.73)$, with none of its items fundamentally reducing its overall reliability. Using Kruskal-Wallis ANOVA and U test, responses were analyzed with respect to university affiliation, sex, and years of teaching experience. Each area of interest brought statistically significant differences and similarities among groups of respondents. The findings complement a broader body of research that has been conducted across the globe to address the impacts of the pandemic on both teachers and learners.
\end{abstract}

2672-8141 @ 2021 Published by European Publisher.

Keywords: Pandemic, university, distance learning, distance teaching, e-learning 


\section{Introduction}

Due to the COVID-19 pandemic and the measures adopted to curb the spread of the virus, educational institutions around the world were forced to search for new ways to keep instruction uninterrupted. With some exceptions regarding vocational study programs, Czech universities remained closed for almost a year (Kramlová \& Mazanec, 2021) from March to June 2020 and then again from October 2020 to June 2021. This unforeseen and unexpectedly long closure pushed teachers to shift instruction to online platforms, adapt to new environments, and face new challenges.

Despite the fact that adequately planned distance learning and blended learning courses are commonly taught in the country, it is assumed that the hasty shift online brought significant complications and radical changes to the educational process. Although teachers could have found information and teaching tips at Ministry of Education's website, many - especially those with no previous experience with online teaching or videoconferencing tools - might have found the situation extremely difficult and stressful. Adedoyin and Soykan (2020) list a wide array of possible challenges. Among them are technological issues, socio-economic factors, human and pets' intrusion, lack of digital competence, problems with assessment and supervision of students, heavy workload, and the question of compatibility of online learning with subjects that are more vocational in nature. However challenging, this unexpected disruption also provided opportunities for professional development and growth (Adedoyin \& Soykan, 2020; Maatuk et al., 2021).

Hvorecký (2020) described the situation at Slovak universities in March 2020, a week after the closure: "only rarely do university websites contain instructions on how to continue teaching. Most teachers do not consider e-learning an equivalent alternative to on-site lectures mostly because they have never done it." It can be assumed that shortly after the introduction of the stay-at-home policy, Czech universities were faced with the same challenges. How did teachers cope with the changes? How was the situation a year after the closure?

Several studies cast some light on the pandemic educational reality in the Czech Republic. For example, Fišerová (2020) investigated perceptions of high school and university students and teachers of economy (177 and 20 respondents, respectively). Regarding teachers' perspective, her results show that most teachers were skeptical about the effectiveness of distance learning, mainly in terms of assessment and feedback. Students mostly missed direct contact with the teacher and quality feedback. Rybenská and Voborníková (2020) explored high schoolers' opinions on the effectiveness of online instruction. In a questionnaire survey with 100 respondents, they found that students were generally satisfied but missed contact with their classmates and the teacher. Rokos and Vančura (2020) focused on views of teachers, pupils, and parents from a selected elementary school. They found that almost half of the teachers were satisfied with online teaching but found some students uncooperative and reported higher workload due to preparation of online teaching materials and correction of assignments. Other negative aspects were a lack of direct communication and the inability to check students' understanding.

Studies dealing with the impact of the pandemic on teaching and learning emerged all over the world. However, the number of papers that focus specifically on teachers' perspective is relatively low in comparison with studies targeting the students' viewpoint. To name a few, Alqudah et al. (2020) used an online questionnaire to investigate the perceptions and experiences with online teaching in twenty-three 
Jordanian academic ophthalmologists. Twelve respondents admitted they had never used e-learning tools before the pandemic, while fifteen of them thought their technical skills were not sufficient, and so enrolled in a special course. Most participants said their experience was good, twelve said they might keep using elearning tools after lockdown.

Lei and So (2021) compared perceptions of teachers and students in tourism and hospitality programs. Their data show that students demonstrated a significantly greater preference for online learning than teachers. Authors theorize that as the teachers in their survey did not have much experience with online teaching prior to the pandemic, this might have influenced their confidence to teach online and affect its perceived effectivity.

Elshami et al. (2021) investigated student and teacher satisfaction. Their results show that faculty members were satisfied with communication and communication tools used in teaching. The areas of most dissatisfaction were higher workload, difficulty motivating students, longer preparation time, and technical problems.

Niemi and Kousa (2021) described one upper secondary school in Finland during a two-month closure of educational institutions. Their data revealed that students mostly complained of heavy workload and loss of motivation. The main challenges for teachers, on the other hand, were non-authenticity of interaction, a lack of spontaneity, and ensuring students' progress.

In light of the recent development, Abaci et al. (2021) and Lockee (2020) reacted to a 2019 article by Philipsen et al. (2019), who analyzed fifteen research articles that deal with professional skills a teacher needs to be able to run a successful e-learning course. Their analysis led to the creation of a framework that should serve as a basis in teacher training. Both Abaci et al. (2021) and Lockee (2020) point to the possibility to look at currently emerging articles of teacher experiences with online teaching during the pandemic and analyze them in a similar same way. This would help in creating a more universal and precise framework.

\section{Problem Statement}

Hodges et al. (2020) came up with the term "emergency remote teaching" to describe pandemicprovoked shift online and contrasted it with "high-quality online education", explaining that the main goal under emergency circumstances is to guarantee reliable and easily accessible instruction and support rather than to present a carefully planned and effective online teaching.

As the closure of Czech universities lasted long enough for departments and teachers to adapt to this "new normal", we assume that the implementation of online classes brought radical changes to communication between the class and the teacher, to content delivery, course organization, classroom dynamics, and assessment.

\section{Research Questions}

This study is based on quantitative and qualitative data. Its main goal was to gather opinions on the pandemic-related changes in four key areas: Preferences, Course, Lesson, and Support. In relation to the objectives of the survey, the following research questions were formulated: 
RQ1: What was respondents' overall experience with online teaching during the pandemic?

RQ2: How did the pandemic affect the organization of the course?

RQ3: How did the pandemic affect the course of the lesson?

RQ4: Did teachers receive sufficient technological support from their institution?

\section{Purpose of the Study}

Since most of the papers dealing with pandemic-provoked online teaching in the Czech Republic target students and/or teachers in lower levels of the educational system, our objective was to gather information about the experience of a specific group of university teachers, i.e., those who teach at language departments of faculties of education across the country. Results found in this study complement the worldwide body of research and may serve as a basis for comparison or further investigation.

The pandemic accelerated the transition to online teaching and might, in its aftermath, reshape education as we know it. We therefore find it vital to understand the struggles and challenges faced by teachers. We believe it is worth understanding the benefits and pitfalls of the current situation from the perspective of the teacher to help future planning and development on university and national level.

\section{Research Methods}

\subsection{Questionnaire}

The author used a self-developed questionnaire. Prior to data collection, selected individuals from the research sample were invited to read and comment on the questionnaire to ensure comprehensibility, clarity, and face validity of the instrument. Based on their comments, some changes were made. The questionnaire reflects author's personal teaching experience during the pandemic, ideas that emerged in informal conversations with colleagues, and comments made during pilot testing. Their purpose is to compare pandemic online teaching with regular face-to-face (abbreviated as F2F) classes even if this not explicitly stated.

The questionnaire was designed in Google Forms and was made available through email. It consisted of a demographic section and four key areas: Preferences, Course, Lesson, and Support. The Preferences section included multiple choice questions; the remaining three sections included 34 items measured using 4-point Likert scale (strongly disagree - disagree - agree - strongly agree). Each section was complemented by a space for optional commentary to provide respondents with the opportunity to address any issue in more detail.

The calculated value (Cronbach's alpha $=0.73$ ) suggests that the reliability of the tool is acceptable.

\subsection{Research sample and data collection}

The study targeted teachers who teach at language departments of Czech faculties of education. Of the total number of universities in the country, nine of them have a faculty of education. Using the mailing lists at the faculties' websites, we contacted a total of 130 faculty members via email. Questionnaires were distributed in March 2021 and data collection lasted until April 2021. Participation in the survey was 
anonymous and voluntary. We gathered data from $\mathrm{N}=70$ participants; $75,7 \%(\mathrm{~N}=53)$ of whom were female. The sample is not representative of the population but does represent its gender structure. Table 1 shows the structure of the research sample with respect to university affiliation. The number of respondents from each university is proportional to the overall size of its language departments (i.e., universities with smaller language departments are represented with a lower number of respondents). Table 2 shows the structure of the research sample with respect to years of teaching experience.

Table 1. Structure of the sample: university affiliation

\begin{tabular}{ll}
\hline University & Number of respondents \\
\hline University 1 & 10 \\
University 2 & 3 \\
University 3 & 19 \\
University 4 & 4 \\
University 5 & 8 \\
University 6 & 9 \\
University 7 & 5 \\
University 8 & 6 \\
University 9 & 6 \\
\hline
\end{tabular}

Table 2. Structure of the sample: years of teaching experience

\begin{tabular}{ll}
\hline Years of teaching experience & Number of respondents \\
\hline $1-5$ & 6 \\
$6-10$ & 9 \\
$11-15$ & 10 \\
$16-20$ & 13 \\
$21-25$ & 12 \\
$26-30$ & 7 \\
$30+$ & 13 \\
\hline
\end{tabular}

\subsection{Data analysis}

Since not all variables had normal distribution, Kruskal-Wallis ANOVA was used to compare the perceptions of teachers from different universities and with respect to their teaching experience. To compare difference between sexes, Mann-Whitney U test was applied. The analysis was performed using STATISTICA 14 by TIBCO Software Inc. (2017).

\section{Findings}

\subsection{Preferences}

The first part of the questionnaire, named Preferences, included multiple choice questions that inquired about respondents' personal choices regarding the place of work and the reasons behind their choice.

The majority ( $\mathrm{N}=54,77 \%)$ said they worked primarily from home during the pandemic. The most common reason was the government's stay-at-home policy (selected by $59 \%$ ), followed by saving time 
$(50 \%)$, safety $(48 \%)$, the need to take care of children or other family members $(39 \%)$, higher comfort working from home $(30 \%)$, better working environment at home $(26 \%)$, and a more reliable internet connection (24\%). Only $7 \%$ of respondents believe that working from home is less stressful than working from the university.

When asked whether they were satisfied with working from home, 36 respondents $(67 \%)$ said they were satisfied. On the other hand, 9 of the 21 respondents who selected "the need to take care of children or other family members" among the reasons to work from home said they would prefer working from the university if their family situation was different.

For those who continued working from university $(\mathrm{N}=16,23 \%)$, the main reason was maintaining work-life balance (selected by $75 \%$ ), a more reliable internet connection (56\%) and a generally better working environment (44\%). Comments to this section reveal that their offices tend to be better equipped with technology and resources. Two participants said they found working in the deserted faculty building very peaceful as opposed to their disorderly homes where their partners and children were also working and studying from home. Habit or the possibility to meet colleagues played only a minor role (both were selected by $6 \%$ ).

\subsection{The course}

The second part of the questionnaire contained 10 Likert-scale items that dealt with changes to the course structure and assessment. Table 3 lists the items together with the p-values obtained in the ANOVA and $\mathrm{U}$ test statistical testing.

Table 3. Results of statistical testing for section A: Course

\begin{tabular}{|c|c|c|c|}
\hline Section A: Course & By university & $\begin{array}{l}\text { By teaching } \\
\text { experience }\end{array}$ & By sex \\
\hline Item & $\begin{array}{c}\text { Kruskal-Wallis } \\
\text { ANOVA } \\
\text { p value }\end{array}$ & $\begin{array}{c}\text { Kruskal-Wallis } \\
\text { ANOVA } \\
\text { p value }\end{array}$ & $\begin{array}{c}\text { Mann-Whitney } \\
\text { U test } \\
\text { p value }\end{array}$ \\
\hline A1: I had to reduce the contents of the course. & 0.64 & 0.51 & 0.53 \\
\hline A2: I had to alter the structure of the course. & 0.31 & $<0.01$ & 0.44 \\
\hline $\begin{array}{l}\text { A3: I had to change the way of presenting the } \\
\text { subject matter. }\end{array}$ & 0.83 & 0.92 & 0.93 \\
\hline $\begin{array}{l}\text { A4: I feel like I can go through less subject matter in } \\
\text { online classes. }\end{array}$ & 0.75 & 0.67 & 0.98 \\
\hline $\begin{array}{l}\text { A5: Online classes are based on self-study more than } \\
\text { F2F classes. }\end{array}$ & 0.93 & 0.92 & 0.97 \\
\hline A6: I had to change the methods of assessment. & 0.05 & 0.07 & 0.02 \\
\hline $\begin{array}{l}\text { A7: I rely on continuous assessment more than in } \\
\text { F2F courses. }\end{array}$ & 0.86 & 0.11 & 0.96 \\
\hline $\begin{array}{l}\text { A8: I believe that online tests are worse for } \\
\text { assessment. }\end{array}$ & 0.68 & 0.19 & 0.69 \\
\hline $\begin{array}{l}\text { A9: I believe it is easier for students to cheat in } \\
\text { online exams. }\end{array}$ & 0.32 & 0.01 & 0.55 \\
\hline $\begin{array}{l}\text { A10: Students used online consultations more often } \\
\text { than F2F consultations. }\end{array}$ & 0.02 & 0.96 & 0.86 \\
\hline
\end{tabular}


Comparison by university shows statistically significant differences in responses to A10 'Students used online consultations more often than F2F consultations'. However, comparison by teaching experience and sex reveals that participants generally agreed with this statement. This suggests a different approach to consultations at each university.

When comparing by teaching experience, great differences were found in A2 'I had to alter the structure of the course', and A9 'I believe it is easier for students to cheat in online exams'. Interestingly, the youngest group of respondents (1-5 years of teaching experience) showed the greatest variance in responses to A9 (Figure 1). Note that in Figures, values on the vertical axis represent degree of agreement with the statement ranging from 0 (strongly disagree) to 3 (strongly agree).

In comparison by sex, statistically significant differences were found in A6 'I had to change the methods of assessment': male respondents were more prone to changing the methods of assessment than female respondents. Comparison by sex also shows that both male and female participants disagreed with statement A4 'I feel like I can go through less subject matter in online classes'. In a commentary, one respondent expressed their surprise at the fact they were able to do even more in an online course.

In addition, significant similarities $(\mathrm{p}>0.8)$ were found in $\mathrm{A} 3$ and $\mathrm{A} 5$ in all three variables: respondents generally agreed they had to alter the way of presenting the subject matter (A3) and that online courses were based on self-study more than regular F2F courses (A5). While results suggest that students were expected to do more work outside of class, respondents generally disagreed with statement A7 'I rely on continuous assessment more than in F2F courses'.

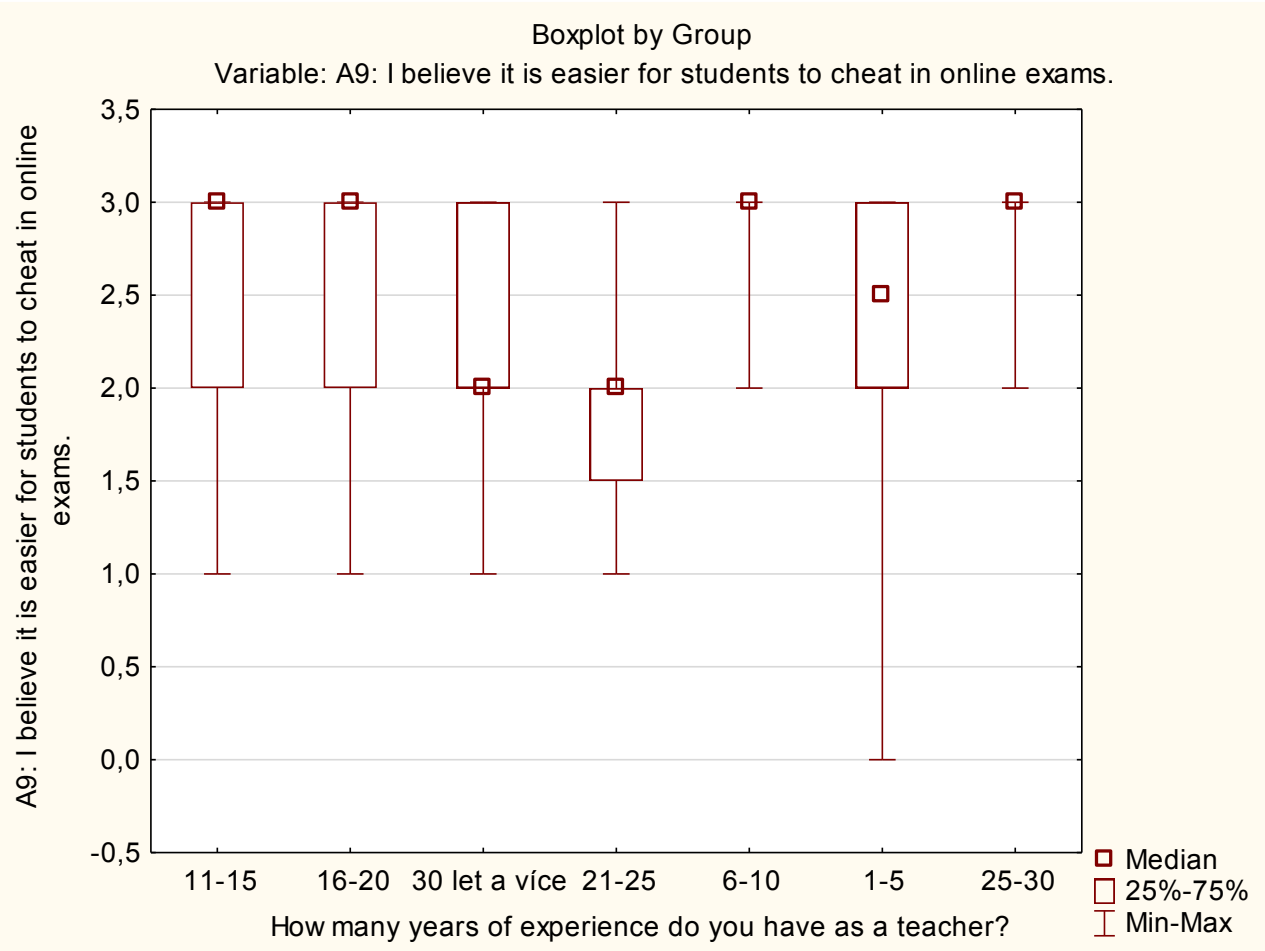

Figure 1. Item A9: comparison by years of experience using the Box \& Whisker Plot 


\subsection{The lesson}

The third section dealt with issues related to class dynamics and some practical aspects of subject matter presentation. The first two items were multiple choice questions that asked about the use of the camera. 57 respondents (81\%) said they always turned their camera on, while $10(14 \%)$ turned it on only occasionally, depending on the situation, and 3 (4\%) said they never turned it on. When asked how they view their students' use of the camera, 40 participants (57\%) admitted they did not like it when students did use the camera, 17 (24\%) said it did not matter to them and 13 (19\%) said they did not care whether their students use the camera or not. In comments, many respondents explained that although they do not feel comfortable speaking to a blank screen, they understand that using the camera slows down the connection, and therefore respect their students' choice not to switch it on. One respondent said their department requires students to always have cameras on and some reported they require students to use the camera during examinations and tests.

The rest of the section contained 18 Likert-scale items. Table 4 shows items included in this section and the p-values obtained in statistical testing.

Table 4. Results of statistical testing for section B: Lesson

\begin{tabular}{|c|c|c|c|}
\hline Section B: Lesson & By university & $\begin{array}{l}\text { By teaching } \\
\text { experience }\end{array}$ & By sex \\
\hline Item & $\begin{array}{l}\text { Kruskal- } \\
\text { Wallis } \\
\text { ANOVA } \\
\text { p value }\end{array}$ & $\begin{array}{c}\text { Kruskal-Wallis } \\
\text { ANOVA } \\
\text { p value }\end{array}$ & $\begin{array}{c}\text { Mann- } \\
\text { Whitney } \\
\text { U test } \\
\text { p value }\end{array}$ \\
\hline $\begin{array}{l}\text { B1: Online classes are more teacher centered than F2F } \\
\text { classes. }\end{array}$ & 0.05 & 0.32 & 0.60 \\
\hline $\begin{array}{l}\text { B2: F2F classes are based on student interaction more than } \\
\text { online classes. }\end{array}$ & 0.26 & 0.76 & 0.38 \\
\hline $\begin{array}{l}\text { B3: I find it harder to provoke a class discussion in online } \\
\text { lessons. }\end{array}$ & 0.22 & 0.74 & 0.86 \\
\hline B4: I must call students out to get a reaction. & 0.88 & 0.51 & 0.56 \\
\hline B5: I use break-out rooms. & 0.77 & 0.22 & 0.01 \\
\hline B6: I find it harder to improvise in online lessons. & 0.63 & 0.52 & 0.13 \\
\hline B7: I miss the spontaneity of F2F lessons. & 0.57 & 0.15 & 0.78 \\
\hline B8: I miss the whiteboard. & 0.62 & 0.04 & 0.11 \\
\hline B9: I miss eye contact. & 0.52 & 0.57 & 0.47 \\
\hline B10: I perform random checks to see if students are present. & 0.26 & 0.09 & 0.54 \\
\hline B11: I believe students pay more attention in F2F lessons. & 0.65 & 0.89 & 0.68 \\
\hline B12: Preparing for online lessons is more time consuming. & 0.65 & 0.20 & 0.26 \\
\hline B13: I appreciate the opportunity to teach from anywhere. & 0.39 & 0.35 & 0.49 \\
\hline $\begin{array}{l}\text { B14: I appreciate the opportunity to share the lesson with } \\
\text { anyone. }\end{array}$ & 0.08 & 0.74 & 0.40 \\
\hline $\begin{array}{l}\text { B15: I find online lessons static (I sit all the time without } \\
\text { moving around). }\end{array}$ & 0.71 & 0.65 & 0.71 \\
\hline B16: Teaching online saves time. & 0.49 & 0.21 & 0.75 \\
\hline B17: I believe that students are happy with online learning. & 0.72 & 0.85 & 0.35 \\
\hline B18: Overally, I am happy with online teaching. & 0.64 & 0.41 & 0.59 \\
\hline
\end{tabular}


In comparison by university, the ANOVA analysis did not show any statistically significant differences. In contrast, respondents across universities generally agreed they had to call students out to get a reaction from them (B4), and comparison by sex showed that participants agreed they found it harder to provoke a class discussion in online classes (B3). This might suggest a lower level of involvement on the part of the students as compared to F2F classes. However, other items related to students' involvement (B1, B2, B7, B9, B10) were not statistically significant.

Comparing by teaching experience showed great differences in responses to B8 'I miss the whiteboard' with the greatest variability among the youngest group of respondents (Figure 2). The youngest group were also most inclined to believe that students were happy with online learning (B17, see Figure 3).

A difference between sexes was found in B5 'I use breakout rooms': female respondents were more likely to use breakout rooms than their male counterparts.

In comments, participants emphasized that each aspect varies depending on the size of the group, type of lesson (lecture versus seminar), whether the students know each other, and the subject matter itself. Their comments often reveal that they were scared and distrustful of the effectiveness and viability of online teaching at the beginning of the pandemic. After a year of online teaching, they have, however, learned to use online applications, created new teaching materials, and discovered new tools. Although they are still acutely aware of its deficiencies in some areas, they have come to appreciate (at least some of) the advantages that online teaching brings.

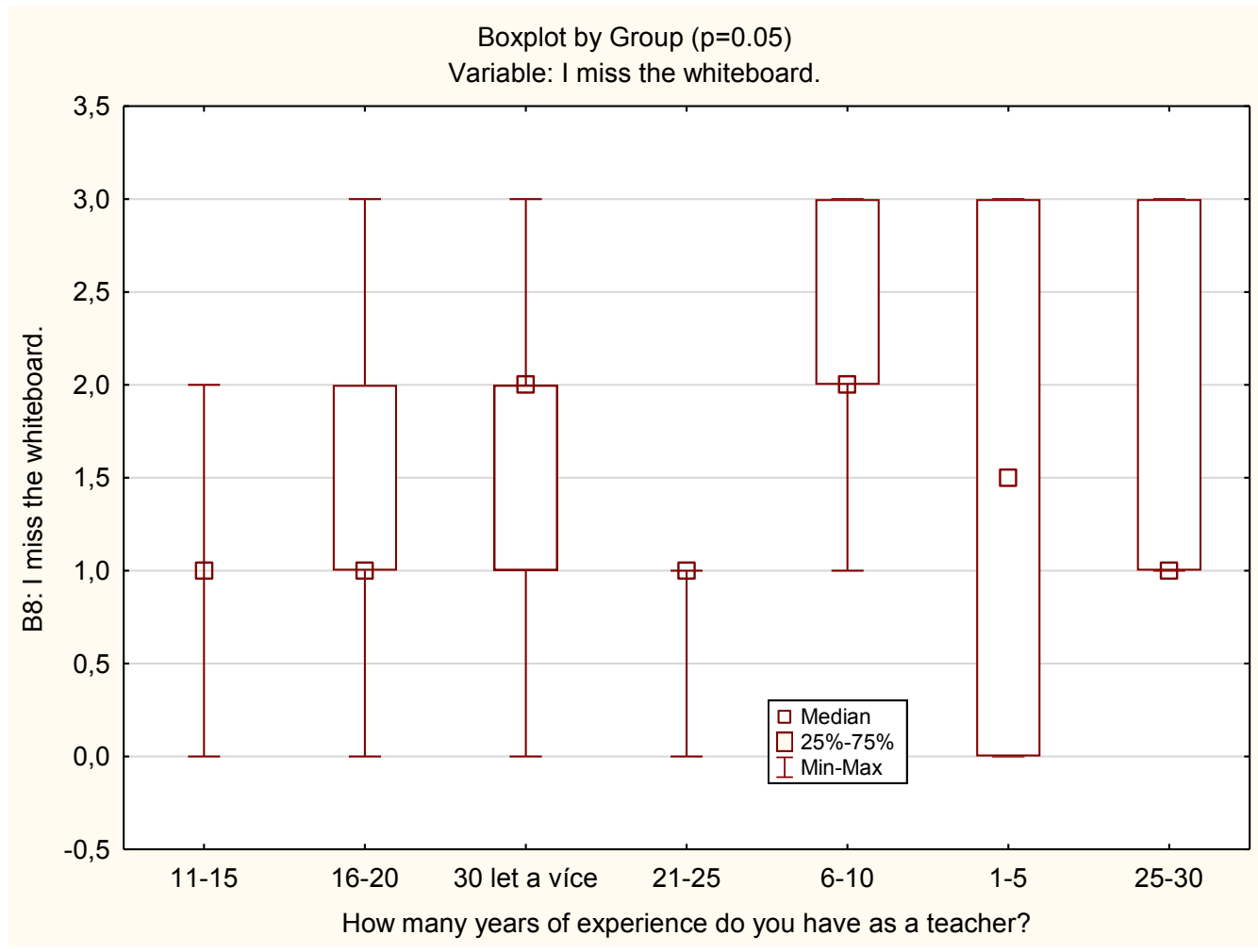

Figure 2. Item B8: comparison by years of experience using the Box \& Whisker Plot 
Boxplot by Group

Variable: B17: I believe that students are happy with online learning.

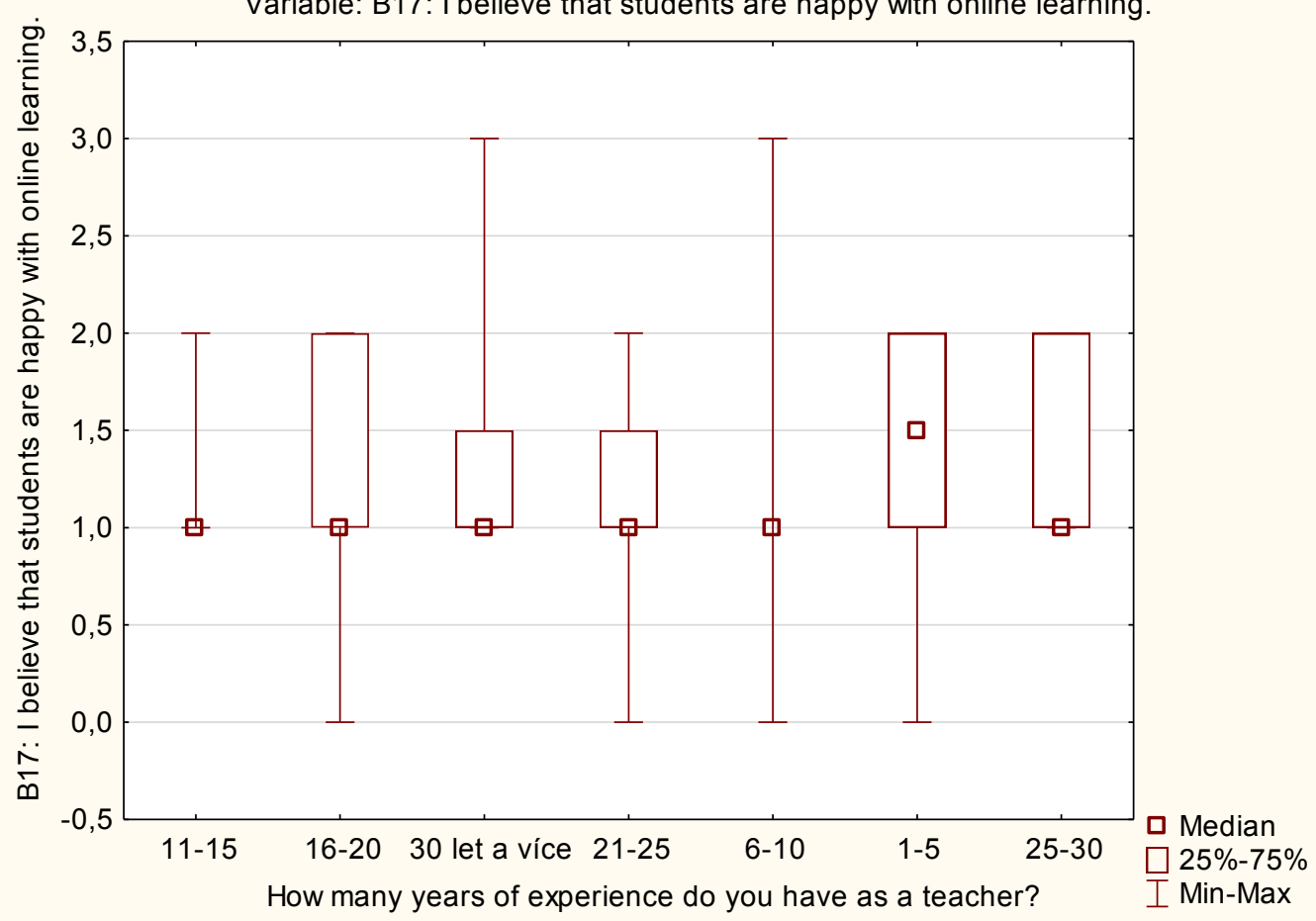

Figure 3. Item B17 by years of experience using the Box \& Whisker Plot

\subsection{Support}

The final section of the questionnaire contained 6 Likert-scale items dealing with technological support from the department/university. Table 5 shows results of the statistical testing.

Table 5. Results of statistical testing for section C: Support

\begin{tabular}{lccc}
\hline Section C: Support & By university & $\begin{array}{c}\text { By teaching } \\
\text { experience }\end{array}$ & By sex \\
\hline Item & $\begin{array}{c}\text { Kruskal- } \\
\text { Wallis } \\
\text { ANOVA } \\
\text { p value }\end{array}$ & $\begin{array}{c}\text { Kruskal- } \\
\text { Wallis } \\
\text { ANOVA } \\
\text { p value }\end{array}$ & $\begin{array}{c}\text { Mann- } \\
\text { Whitney } \\
\text { U test } \\
\text { p value }\end{array}$ \\
\hline $\begin{array}{l}\text { C1: The whole department uses the same tool for online } \\
\text { teaching. }\end{array}$ & 0.02 & 0.12 & 0.08 \\
$\begin{array}{l}\text { C2: Everybody at the department was free to choose a } \\
\text { tool for online teaching. }\end{array}$ & $<0.01$ & 0.30 & 0.84 \\
$\begin{array}{l}\text { C3: The department provided enough technological } \\
\text { support. }\end{array}$ & 0.86 & 0.63 & 0.98 \\
C4: I had an opportunity to attend a workshop or a & & & 0.31 \\
course to learn how to use a tool. & 0.50 & 0.81 & 0.94 \\
$\begin{array}{l}\text { C5: I had to learn myself how to use the tool. } \\
\text { C6: I could turn to someone at the department in case of } \\
\text { technological issues. }\end{array}$ & 0.40 & 0.12 & 0.78 \\
\hline
\end{tabular}


Comparison by university showed statistically significant differences in $\mathrm{C} 1$ 'The whole department uses the same tool for online teaching' and C2 'Everybody at the department was free to choose a tool for online teaching'. Results in both items suggest that each university adopted a different approach and some of them used the same platform across the board to ensure uniformity. Comparison by university and sex revealed that respondents were satisfied with the level of technological support they received as most agreed with C3 'The department provided enough technological support'. In addition to continuous support, participants generally agreed they had an opportunity to attend a workshop or a course (C4), which is in line with results of comparison by sex, where both males and females agreed they were not left to sink and did not have to learn how to use an application themselves (C5). Respondents commented that although their institution offered a workshop or another form of help, they often did not take this opportunity and preferred to learn to use an application "by trial and error".

Comments to this section reveal a high level of satisfaction as most comments were positive, for example, one participant wrote: "Our university's reaction to the situation was very effective, fast, and they were beyond helpful in case of any troubles".

\section{Conclusion}

Although participants taught from home mainly due to the state-wide measures and to ensure their personal safety, reasons such as saving time and taking care of other family members also scored high. Most of them were satisfied working from home. On the other hand, some of their colleagues preferred working from the university, mainly to maintain work-life balance and because of a more reliable connection and a generally better working environment.

Regarding the course, results show that changes to the course structure were not as dramatic as was expected. Although respondents were able to get through the same amount of subject matter as in regular classes, results show they also relied on students' self-study more heavily than in F2F classes. Both findings suggest that in-class work might have been complemented by a larger number of assignments. This might have caused a higher workload on the part of the student. The upper secondary school students in Niemi and Kousa's (2021) study reported a heavier workload. The same study also showed that teachers emphasized they had to adapt methods of assessment, which is in direct contrast findings of this study. This can be explained by the fact that Niemi and Kousa (2021) investigated perceptions of students and teachers at a secondary school and by the fact that the school closure in Finland only lasted two months. The prolonged closure in the Czech Republic and the nature of university subjects can explain the found differences.

In terms of class dynamics, participants emphasized that there exist great differences between groups, types of classes, and subjects. Although two items hinted at the possibility of lower student involvement in online classes, most items related to this aspect did not show as statistically significant. Moreover, a seemingly lower involvement might be caused by other factors as well, such as shyness (especially in groups where students do not know each other in person) or quality of connection.

The last section dealt with support provided by universities and showed very encouraging results. Participants generally agreed that their departments/universities did not leave them stranded and provided them with enough information and support. However, it must be kept in mind that the present survey was 
conducted a year after the introduction of the measures. By the time of data collection, universities had had enough time to adapt to the "new normal" and teachers had been teaching online for almost a year. The survey therefore does not describe the situation at its worse but captures the many facets of pandemic online teaching after the situation has calmed down and respondents had time to re-evaluate their initial assumptions and possible fears.

The study has several limitations. One of them is the low number of respondents which is by no means representative of the whole population. Another problematic aspect is the fact that although respondents came from similar institutional background (i.e., teachers who work at language departments of Czech faculties of education), even within such a narrow subject area there exist several specializations from syntax to phonetics, practical language, or literature, which can be taught in lectures, practical seminars, discussion groups, etc. Each form has its peculiarities, as well as each group of students. When interpreting the results, it is therefore vital to bear in mind they may be rather general. As a preliminary research, its main purpose was to shed some light on the complex reality of online teaching at departments of education during the pandemic. Found results will serve as a basis for further investigation.

\section{Acknowledgments}

The paper was supported by the project IGA_PdF_2020_012 "Perceptions of the pandemic online teaching: experiences of teachers from Czech faculties of education” by Hana Pavlisová.

\section{References}

Abaci, S., Robertson, J., Linklater, H., \& McNeill, F. (2021). Supporting school teachers' rapid engagement with online education. Educational Technology Research and Development, 69, 29-34. https://doi.org/10.1007/s11423-020-09839-5

Adedoyin, O. B., \& Soykan, E. (2020). Covid-19 pandemic and online learning: the challenges and opportunities. Interactive Learning 1-13. https://doi.org/10.1080/10494820.2020.1813180

Alqudah, N. M., Hisham, M. J., Saleh, O., Khader, Y., Obeidat, N., \& Alqudah, J. (2020). Perception and experience of academic Jordanian ophthalmologists with E-Learning for undergraduate course during the COVID-19 pandemic. Annals of Medicine and Surgery, 59, 44-47. https://doi.org/10.1016/j.amsu.2020.09.014

Elshami, W., Taha, M. H., Abuzaid, M., Saravanan, C., Al Kawas, S., \& Abdalla, M. E. (2021). Satisfaction with online learning in the new normal: perspective of students and faculty at medical and health sciences colleges. Medical Education Online, 26(1). https://doi.org/10.1080/10872981.2021.1920090

Fišerová, M. (2020). Zkušenosti s distanční výukou ekonomických předmětů na středních a vysokých školách $\mathrm{v}$ době koronavirové pandemie. [Experiences with distance teaching of economy subjects at high schools and universities during the Covid pandemic]. Media4u Magazine, 17(4), 6-11.

Hodges, C., Moore, S., Trust, T., \& Bond, A. (2020). The Difference Between Emergency Remote Teaching and Online Learning. https://er.educause.edu/articles/2020/3/the-difference-between-emergencyremote-teaching-and-online-learning

Hvorecký, J. (2020, March 26). Musí být vysoké školy zavřené? [Must universities be closed?] Vedavyzkum. https://vedavyzkum.cz/blogy-a-komentare/jozef-hvorecky/musi-byt-vysoke-skolyzavrene

Kramlová, J., \& Mazanec, P. (2021, July 1). Přednášky v kuchyni i ve vaně. Po roce výuky na dálku převládá demotivace a osamělost [Studying from the kitchen or the bath. After a year of distance 
learning, demotivation and loneliness prevail]. Aktuálně. https://zpravy.aktualne.cz/domaci/rokdistancni-vyuky/r b 979d14cd95b11ebb91a0cc47ab5f122/

Lei, S. I., \& So, A. S. I. (2021). Online Teaching and Learning Experiences During the COVID-19 Pandemic - A Comparison of Teacher and Student Perceptions. Journal of Hospitality \& Tourism Education, 33(3), 148-162. https://doi.org/10.1080/10963758.2021.1907196

Lockee, B. B. (2020). Shifting digital, shifting context: (re)considering teacher professional development for online and blended learning in the COVID-19 era. Educational Technology Research and Development. https://doi.org/10.1007/s11423-020-09836-8

Maatuk, A. M., Elberkawi, E. K., Aljawarneh, S., Rashaideh, H., \& Alharbi, H. (2021). The COVID-19 pandemic and E-learning: challenges and opportunities from the perspective of students and instructors. Journal of Computing in Higher Education. https://doi.org/10.1007/s12528-021-092742

Niemi, H. M., \& Kousa, P. A. (2021). Case Study of Students' and Teachers' Perceptions in a Finnish High School during the COVID Pandemic. International Journal of Technology in Education and Science (IJTES), 4(4), 352-369. https://doi.org/https://doi.org/10.46328/ijtes.v4i4.167

Philipsen, B., Tondeur, J., Pareja Roblin, N., Vanslambrouck, S., \& Zhu, C. (2019). Improving teacher professional development for online and blended learning: a systematic meta-aggregative review. Educational Technology Research and Development, 67(5), 1145-1174. https://doi.org/10.1007/s11423-019-09645-8

Rokos, L., \& Vančura, M. (2020). Distanční výuka při opatřeních spojených s koronavirovou pandemií pohled očima učitelů, žáků a jejich rodičů [Distance learning and teaching under the covid-related restrictions - a perspective of teachers, pupils and their parents]. Pedagogická orientace, 30(2), 122155. https://doi.org/10.5817/PedOr2020-2-122

Rybenská, K., \& Voborníková, M. (2020). Vyučování informatiky a středních školách v době karantény z pohledu studentů. [Teaching IT at high schools during quarantine from the students' perspective]. Media4u Magazine, 17(4), 12-16.

TIBCO Software Inc. (2017). Statistica (data analysis software system), version 13. http://statistica.io 